\title{
Pengaruh Pemberian Oksigen Hiperbarik terhadap Kadar LDL Tikus Putih (Rattus norvegicus) Galur Sprague dawley yang kemudian Diberi Diet Tinggi Lemak
}

\author{
Ika Apriyanti Arum Putri ${ }^{1 *}$, Herin Setianingsih ${ }^{2}$ \\ Fakultas Kedokteran Universitas Hang Tuah Surabaya ${ }^{1}$ \\ Departemen Anatomi Fakultas Kedokteran Universitas Hang Tuah Surabaya ${ }^{2}$ \\ *e-mail: apriyantiarum97@gmail.com
}

\begin{abstract}
Abstrak
Menurut WHO (2017), dari seluruh kematian akibat penyakit kardiovaskular 7,4 juta (42,3\%) di antaranya disebabkan oleh Penyakit Jantung Koroner (PJK). Lipid, khususnya low density lipoprotein (LDL) merupakan salah satu faktor penting penyebab terjadinya PJK, mengingat perannya dalam proses aterogenesis. Terapi Oksigen Hiperbarik diketahui dapat menurunkan faktor resiko atherosklerosis seperti hiperkolesterolemia pada tekanan 1,5 ATA dan 3 ATA. Hiperkolesterolemia ini ditandai dengan peningkatan pada trigliserida (TG), LDL, dan penurunan HDL. Penelitian ini bertujuan untuk mengetahui pengaruh terapi oksigen hiperbarik terhadap kadar LDL tikus putih (Rattus norvegicus) galur Sprague dawley yang kemudian diberi diet tinggi lemak. Penelitian ini adalah penelitian eksperimental murni laboratoris. Subjek pada penelitian ini adalah 32 tikus putih (Rattus norvegicus) galur Sprague dawley yang dibagi menjadi dua kelompok yakni kelompok kontrol dan perlakuan. Kelompok kontrol diberikan diet tinggi lemak selama 49 hari dan kelompok perlakuan yang diterapi oksigen hiperbarik dengan kadar oksigen 98\% tekanan 2,4 ATA selama 10 hari kemudian diberi diet tinggi lemak selama 49 hari. Hasil penelitian didapatkan rata-rata LDL kelompok kontrol sebesar 63,43 $\mathrm{mg} / \mathrm{dl}$ dan kelompok perlakuan adalah $44,43 \mathrm{mg} / \mathrm{dl}$. Kemudian, dilakukan uji hipotesa menggunakan metode Mann Whitney dan didapatkan nilai signifikansi (p) adalah 0,004 atau $p<\alpha$ sehingga dapat ditarik kesimpulan bahwa pada penelitian ini ada perbedaan kadar LDL darah tikus pada kedua kelompok perlakuan atau $\mathrm{H}_{1}$ diterima. Terapi oksigen hiperbarik berpengaruh terhadap penurunan kadar LDL darah pada tikus putih (Rattus norvegicus) galur Sprague dawley sebelum diberi diet tinggi lemak.
\end{abstract}

Kata Kunci: HBOT, LDL, diet tinggi lemak.

\section{The Effect of Hyperbaric Oxygen on LDL Levels in Sprague dawley Rats (Rattus norvegicus) Fed with High Fat Diet}

\begin{abstract}
WHO (2017) stated out of all deaths caused by cardiovascular disease, approximately 7,4 millions deaths (42,3\%) were caused by Coronary Heart Disease (CHD). Lipid, especially low density lipoprotein (LDL), is one of important factors for Coronary Heart Disease (CHD), considering its role in atherogenesis process. Hyperbaric oxygen therapy can reduce one of risk factors of development of atherosclerosis such as hypercholesterolemia at pressure of 1,5 ATA and 3 ATA. Hypercholesterolemia is condition of reducing TG, LDL levels and increasing HDL level. This study aimed to analyse the effect of hyperbaric oxygen on LDL levels in Sprague
\end{abstract}


Pengaruh Pemberian Oksigen Hiperbarik terhadap Kadar LDL Tikus Putih (Rattus norvegicus)...

Ika Apriyanti Arum Putri, Herin Setianingsih

dawley rats (Rattus norvegicus) before fed with high fat diet. This study was a true experimental research. Subjects of this study were 32 Sprague dawley rats (Rattus norvegicus) which were divided into two groups; control group and experimental group. The control group was given high fat diet for 49 days and experimental group was given hyperbaric oxygen with $98 \%$ level of oxygen at pressure of 2,4 ATA for 10 days, then proceeded to be given a high fat diet for 49 days. The results of this study showed that average level of $L D L$ of control group was $63,43 \mathrm{mg} / \mathrm{dl}$ and experimental group was $44,43 \mathrm{mg} / \mathrm{dl}$. The result of analytical study using Mann Whitney showed the significance $(p)$ is 0,004 or $p<\alpha$ or $H_{1}$ is accepted. The conclusion is hyperbaric oxygen therapy has an effect on decreasing $L D L$ levels of Sprague dawley rats (Rattus norvegicus) then fed with high fat diet.

Keywords: HBOT, LDL, high fat diet.

\section{PENDAHULUAN}

Menurut WHO (2017), penyakit kardiovaskular merupakan penyebab kematian nomor satu di dunia. Pada tahun 2015, WHO memperkirakan sebanyak 17,7 juta orang di dunia meninggal akibat penyakit kardiovaskular. Jumlah ini merupakan 31\% dari total kematian di dunia. Dari seluruh kematian akibat penyakit kardiovaskular 7,4 juta $(42,3 \%)$ di antaranya disebabkan oleh Penyakit Jantung Koroner, penyakit kardiovaskular. Terutama penyakit jantung koroner, diduga sebagai penyebab terjadinya peningkatan penderita dengan stroke mencapai 23,3 juta kematian pada tahun 2030 (Kemenkes RI, 2017 ; Kemenkes RI, 2014). Berbagai penelitian menunjukkan bahwa faktor lain yang dapat menyebabkan timbulnya penyakit kardiovaskular adalah gangguan atau perubahan kadar lemak dalam darah (dislipdemia). Gangguan ini dapat berupa peningkatan kadar kolesterol total atau hiperkolesterolemia, penurunan kadar HDL
(High Density Lipoprotein), peningkatan kadar LDL (Low Density Lipoprotein) atau peningkatan kadar trigliserida dalam darah atau hipertrigliserida (Rustika dan Oemati, 2014). Pernyataan serupa juga dinyatakan oleh Xuan Gao dan Shunjun Yua (2010) bahwa level kolesterol plasma adalah indikator kunci dari resiko berkembangnya penyakit kardiovaskular. Low-density lipoprotein cholesterol (LDL-C) dan Highdensity lipoprotein cholesterol (HDL-C) level adalah dua faktor resiko utama. Tingginya konsentrasi LDL-C berhubungan erat dengan penyakit kardiovaskular. Menurut penelitian kedokteran molekuler terbaru, didapatkan bahwa jenis dislipidemia yang paling berbahaya adalah dislipidemia aterogenik. Deposit kolesterol LDL dislipidemia aterogenik terjadi pada dinding pembuluh darah arteri. Hal ini juga menjadi salah satu penyebab terjadinya disfungsi endotel sebagai proses awal terbentuknya plak aterosklerosis. Lipid, khususnya Low Density Lipoprotein (LDL) 
saat ini mulai banyak diteliti karena diduga sebagai prediktor terjadinya Penyakit Jantung Koroner (PJK) mengingat perannya dalam proses aterogenesis (Ma'rufi dan Rosita, 2014).

Aterosklerosis ditandai adanya lesi pada intima dikenal dengan atheroma (atau ateromatosa atau plak aterosklerotik). Plak ateromatosa adalah lesi berupa penonjolan yang terdiri atas pusat massa lemak lunak (terutama kolesterol dan ester kolesterol, dengan partikel nekrotik) ditutupi oleh jaringan ikat. Plak aterosklerotik dapat menyumbat lumen pembuluh darah dan rentan terhadap ruptur, sehingga menghasilkan thrombosis pembuluh darah yang berbahaya. Plak juga melemahkan tunika media, karena dapat mengakibatkan pembentukan aneurisma. Prevalensi dan tingkat keparahan aterosklerosis dan Penyakit Jantung Koroner (PJK) telah dikorelasikan dengan sejumlah faktor resiko dalam beberapa penelitian prospektif (misalnya Framingham Heart Study). Beberapa faktor resiko tidak dapat dikontrol, sedangkan faktor resiko lain dapat diubah atau dikontrol seperti gaya hidup atau perilaku tidak benar (perokok aktif, peminum alkohol, pola makan yang tidak seimbang dan kurangnya olah raga) dapat memperburuk keadaan dari penderita. (Kumar et al, 2013).
Aterosklerosis menyebabkan CHD (Coronary Heart Disease) Pada aterosklerosis adalah berkurangnya aliran darah dan oksigen ke jantung sehingga dapat menyebabkan miokard infark. Penyakit jantung koroner ini juga berhubungan dengan penyempitan arteri, dan menyebabkan berkurangnya aliran darah dan suplai oksigen ke jantung. Pada studi mengenai terapi oksigen hiperbarik (HBO), disebutkan bahwa terapi oksigen hiperbarik mempunyai manfaat untuk kondisi iskemik (Setianingsih et al, 2018).

Hyperbaric oxygen therapy (HBOT) pada manusia dengan cara inhalasi 100\% oksigen pada ruangan (chamber) yang bertekanan 2.0 sampai 2.5 tekanan atmosfer absolut (ATA). Tekanan ini meningkatkan konten oksigen terlarut di atas level fisiologis, berdasarkan tiga hukum gas. Secara singkat, karena gas tubuh ideal berada pada temperatur konstan, volume berbanding terbalik dengan tekanan (Hukum Boyle). Kelarutan suatu gas adalah sebanding dengan tekanan gas pada equilibrium dengan cairan (Hukum Henry). Difusi gas adalah sebanding dengan gradien konsentrasi (Hukum Fick). Berdasarkan hukum-hukum ini, HBOT menginduksi beberapa efek fisiologis seperti reduksi gelembung udara, meningkatkan oksigenasi, vasokonstriksi, aktivitas antimikroba dan angiogenesis 
Pengaruh Pemberian Oksigen Hiperbarik terhadap Kadar LDL Tikus Putih (Rattus norvegicus)... Ika Apriyanti Arum Putri, Herin Setianingsih

(Ishibashi et al, 2014). Hyperbaric oxygen therapy (HBOT) adalah menggunakan $100 \%$ oksigen pada tekanan yang lebih tinggi dari tekanan atmosfer. Saat ini beberapa aplikasi dan indikasi medis dapat menggunakan HBOT. Hyperbaric oxygen therapy sudah berhasil digunakan sebagai terapi pendamping untuk penyembuhan luka (wound healing). Non-healing wound seperti ulcer diabetes dan insufisiensi vaskular merupakan area utama oleh ahli hiperbarik telah diuji melalui berbagai penelitian dan percobaan. HBOT juga dapat diindikasikan terhadap luka infeksi seperti clostridial myonecrosis, infeksi jaringan lunak yang nekrosis, Fournier's gangrene, juga pada luka trauma, injuri kecelakaan, sindrom kompartemen, pembedahan jaringan kulit (skin graft) dan luka bakar. HBOT juga dapat diaplikasikan terhadap luka akibat radiasi, terutama osteoradionecrosis dari mandibular cystitis, dan proctitis (Bhutani dan Vishwanath, 2012). Setianingsih dan Suryokusumo (2015) melaporkan bahwa terapi oksigen hiperbarik (OHB) dapat menurunkan salah satu faktor resiko aterosklerosis dalam hal ini adalah hiperkolesterolemia. Selain itu juga menunjukkan bahwa OHB dapat menurunkan kadar TG, LDL, dan meningkatkan HDL pada tekanan 1,5 ATA dan 3 ATA. Tujuan penelitian ini adalah untuk menganalisa efek dari terapi oksigen hiperbarik terhadap kadar LDL tikus putih (Rattus norvegicus) galur Sprague dawley yang kemudian diberi diet tinggi lemak.

\section{BAHAN DAN METODE}

\section{Populasi Dan Sampel}

Desain penelitian ini merupakan penelitian eksperimental murni laboratoris. Metode penelitian yang digunakan pada penelitian ini yaitu Post Test Control Group Design. Populasi dalam penelitian ini adalah tikus putih (Rattus norvegicus) galur Sprague dawley. Kriteria inklusi meliputi hewan coba berumur 2 bulan, berat badan 110-120 gram, dan jenis kelamin jantan. Kriteria eksklusi meliputi cacat tubuh dan sakit dalam dua minggu pada saat adaptasi, yang dapat dilihat dari bulu yang kasar dan sedikit tegak, serta mobilitas yang berkurang. Total sampel pada penelitian ini adalah 32 ekor tikus putih (Rattus norvegicus) galur Spargue dawley yang dibagi ke dalam dua kelompok yakni kelompok kontrol ( $\mathrm{Pa}$ ) dan kelompok perlakuan $(\mathrm{Pb})$. Kelompok kontrol $(\mathrm{Pa})$ adalah kelompok yang diberi diet lemak selama 49 hari tanpa diterapi oksigen hiperbarik. Kelompok perlakuan (Pb) adalah kelompok tikus yang diterapi oksigen hiperbarik selama 10 hari, kemudian diberi diet tinggi lemak selama 49 hari. Total waktu penelitian adalah 73 hari dengan rincian 14 hari proses adaptasi, 
10 hari diterapi oksigen hiperbarik dan 49 hari diet tinggi lemak.

\section{Oksigen Hiperbarik}

Terapi oksigen hiperbarik diberikan pada kelompok perlakuan (Pb) dengan tekanan 2,4 ATA $3 \times 30$ menit/sesi dengan 5 menit periode air break, kadar oksigen 98\% dan dilakukan di dalam chamber hiperbarik selama 10 hari.

\section{Diet Tinggi Lemak}

Diet aterogenik diberikan pada tikus dengan kriteria berat badan 110-120 gram. Pemberian diet aterogenik dilakukan dengan pemberian asam kolat melalui sonde dengan dosis $64 \mathrm{mg} /$ ekor/hari dan pakan aterogenik dengan komposisi campuran dari comfeed PAR-S 50\%, terigu $25 \%$, kolesterol $2 \%$, minyak babi $2,5 \%$ tepung kanji 20,5\% dan air, yang dibuat pellet seberat masing-masing 60 gram yang kemudian dikeringkan.

Penelitian ini dilaksanakan di dua tempat yakni Laboratorium Embriologi di Fakultas Kedokteran Hewan Universitas Airlangga Surabaya untuk perlakuan melalui pemberian diet tinggi lemak dan Laboratorium Hiperbarik di Universitas Hangtuah Surabaya untuk perlakuan melalui terapi oksigen hiperbarik.
Pemilihan tekanan oksigen sebesar 2,4 ATA pada penelitian ini mengacu pada penelitian yang dilakukan oleh Setianingsih dan Suryokusumo (2015). mengenai efek terapi oksigen hiperbarik (OHB) dalam menurunkan salah satu faktor resiko atherosklerosis yaitu hiperkolesterolemia, yang menunjukkan OHB dapat menurunkan kadar TG, LDL, dan meningkatkan HDL pada tekanan 1,5 ATA dan 3 ATA

\section{Analisa Data}

Sampel darah diambil, diberi label sesuai kelompok dan nomor tikus, kemudian dibawa ke Balai Besar Laboratorium Kesehatan Surabaya untuk pemeriksaan kadar kolesterol LDL darah dengan metode homogenous menggunakan alat spektrofotometer. Data yang diperoleh dari laboratorium diperiksa kelengkapannya. Kemudian, data diolah dan dianalisis menggunakan program SPSS dengan metode Mann Whitney. Bila hasil uji Mann Whitney menghasilkan signifikansi (p) <0,05, berarti terdapat perbedaan bermakna.

\section{HASIL}

Berikut adalah hasil pemeriksaan kadar LDL pada 32 sampel tikus yang dibagi menjadi 2 kelompok. 
Pengaruh Pemberian Oksigen Hiperbarik terhadap Kadar LDL Tikus Putih (Rattus norvegicus)... Ika Apriyanti Arum Putri, Herin Setianingsih

Tabel 1. Data hasil pengukuran dan analisis LDL

\begin{tabular}{lccc}
\hline \multirow{2}{*}{ Variabel } & \multirow{2}{*}{ Nomor } & \multicolumn{2}{c}{ Kelompok } \\
\cline { 2 - 4 } & 1 & 59 & $\mathrm{~Pb}$ \\
\hline & 2 & 44 & 40 \\
& 3 & 45 & 47 \\
& 4 & 43 & 42 \\
& 5 & 66 & 51 \\
& 6 & 39 & 41 \\
Kadar LDL & 7 & 46 & 54 \\
(mg/dL) & 8 & 65 & 42 \\
& 9 & 83 & 51 \\
& 10 & 52 & 41 \\
& 11 & 86 & 54 \\
& 12 & 51 & 55 \\
& 13 & 61 & 43 \\
& 14 & 78 & 40 \\
Nilai Maksium & 15 & 98 & 21 \\
& 16 & 99 & 34 \\
\hline Ratai Minimum & & 63,43 & 44,43 \\
& & 99 & 55 \\
& & 39 & 21 \\
\hline
\end{tabular}

Berdasarkan Tabel 1 didapatkan hasil rerata kadar LDL kelompok kontrol Pa adalah 63,43 , nilai maksimum 99 , dan nilai minimum sebesar 55 . Selanjutnya, untuk kelompok perlakuan $\mathrm{Pb}$ didapatkan data hasil penelitian rerata kadar LDL sebesar 44,43, nilai maksimum 55, dan nilai minimum 21.

\section{Uji Normalitas}

Tabel 2. Uji normalitas menggunakan metode Saphiro-Wilk

\begin{tabular}{llcrrrrr}
\hline & & \multicolumn{3}{c}{ Kolmogorov-Smirnov $^{\mathrm{a}}$} & \multicolumn{3}{c}{ Shapiro-Wilk } \\
\hline & Nama & Statistic & Df & \multicolumn{1}{c}{ Sig. } & Statistic & df & \multicolumn{1}{c}{ Sig. } \\
\hline \multirow{2}{*}{ LDL } & Kelompok Pa & .155 & 16 & $.200^{*}$ & .909 & 16 & .110 \\
& Kelompok Pb & .187 & 16 & .137 & .889 & 16 & .053 \\
\hline
\end{tabular}

Berdasarkan tabel uji normalitas di atas, didapatkan hasil pada kelompok $\mathrm{Pa}$ adalah $(p=0,110)$ dan pada kelompok $\mathrm{Pb}$ adalah sebesar $(p=0,053)$ memberi makna bahwa nilai (p) dari masing-masing kelompok lebih besar dari alpha $(p>\alpha)$ datanya berdistribusi normal.

\section{Uji Homogenitas Variansi Data}

Tabel 3. Uji homogenitas variansi data metode Levene

\begin{tabular}{llll}
\hline $\begin{array}{l}\text { Levene } \\
\text { Statistic }\end{array}$ & df1 & df2 & Sig. \\
\hline 10.115 & 1 & 30 & .003 \\
\hline
\end{tabular}

Berdasarkan Uji Levene pada tabel di atas, didapatkan $(p=0,003)$ atau $p<\alpha$ yang berarti data dalam penelitian ini bersifat 
heterogen. Dengan demikian penelitian ini tidak memenuhi syarat uji statistika parametrik dilanjutkan dengan uji statistika non parametrik menggunakan uji Mann Whitney.

\section{Uji Mann Whitney}

Tabel 4. Uji statistika Mann Whitney

\begin{tabular}{ll}
\hline & LDL \\
\hline Mann-Whitney U & 51.500 \\
Wilcoxon W & 187.500 \\
Z & -2.886 \\
Asymp. Sig. (2-tailed) & .004 \\
Exact Sig. [2*(1-tailed Sig.)] & $.003^{\mathrm{b}}$ \\
\hline
\end{tabular}

Pada uji hipotesa menggunakan metode Mann Whitney adalah $(p=0,004)$ atau $p<\alpha$ sehingga dapat ditarik kesimpulan bahwa pada penelitian ini ada perbedaan kadar LDL darah tikus pada kedua kelompok perlakuan atau $\mathrm{H}_{1}$ diterima.

\section{PEMBAHASAN}

Penelitian ini adalah penelitian eksperimental laboratoris untuk mengetahui pengaruh terapi oksigen hiperbarik terhadap kadar LDL tikus putih (Rattus norvegicus) galur Sprague dawley yang kemudian diberi diet tinggi lemak. Berdasarkan Tabel 1, didapatkan data ratarata LDL kelompok Pa kelompok kontrol atau kelompok diberikan diet tinggi lemak yakni sebesar $63,43 \mathrm{mg} / \mathrm{dl}$ tanpa diterapi oksigen hiperbarik dan kelompok $\mathrm{Pb}$ atau kelompok diterapi dengan oksigen hiperbarik dan dilanjutkan diinduksi diet tinggi lemak adalah sebesar $44,43 \mathrm{mg} / \mathrm{dl}$. Menurut Sigit (2010), ambang batas normal LDL pada tikus adalah 7-27,2 mg/dl. Apabila kita membandingkan kadar normal LDL tikus tersebut dengan hasil penelitian rerata $\mathrm{LDL}$ pada kelompok $\mathrm{Pa}$ dan $\mathrm{Pb}$ maka kedua kelompok ini memiliki kadar LDL di atas ambang normal LDL. Pada penelitian ini kelompok $\mathrm{Pb}$ atau kelompok perlakuan diterapi dengan oksigen hiperbarik kadar LDL cenderung lebih rendah dibandingkan kelompok kontrol Pa. Pada penelitian ini diberikan diet aterogenik yakni pemberian asam kolat melalui sonde dengan dosis 64 $\mathrm{mg} /$ ekor/hari dan pemberian pakan aterogenik dengan komposisi campuran dari comfeed PAR-S 50\%, terigu 25\%, kolesterol $2 \%$, minyak babi $2,5 \%$, tepung kanji $20,5 \%$ dan air yang dibuat pellet seberat masing-masing 60 gram kemudian dikeringkan. Comfeed PAR-S merupakan diet normal standar yang biasa digunakan dalam penelitian dan merupakan pakan unggas untuk ayam buras yang biasanya diberikan saat unggas masih kecil dengan tujuan agar unggas menjadi lebih gemuk. Minyak babi memiliki komposisi asam lemak jenuh (miristat 1\%, palmitat $25 \%$ dan stearate 15\%) dan asam lemak tak jenuh (oleat $50 \%$, linoleat $6 \%$, dan sisanya 3\%) (McMurry, 2000) dalam Noor Nailis Sa'adah dan Rarastoeti Pratiwi (2016). Diet 
Pengaruh Pemberian Oksigen Hiperbarik terhadap Kadar LDL Tikus Putih (Rattus norvegicus)... Ika Apriyanti Arum Putri, Herin Setianingsih

lemak jenuh dapat meningkatkan konsentrasi kolesterol darah sebesar 1525\%. Hal ini disebabkan peningkatan penimbunan lemak, yang menimbulkan peningkatan jumlah pada asetil-KoA dalam sel hati untuk menghasilkan kolesterol (Guyton (1994) dalam Noor Nailis Sa'adah dan Rarastoeti Pratiwi (2016)). Untuk menjelaskan lebih lanjut alasan penggunaan diet atherogenik yang digunakan dalam penelitian ini, untuk membandingkan penelitian ini dengan penelitian lain tentang induksi diet aterogenik dengan komposisi diet yang hampir sama seperti pada penelitian ini. Penelitian Teuku Heriansyah (2013) yang berjudul Pengaruh Berbagai Durasi Pemberian Diet Tinggi Lemak Terhadap Profil Lipid Tikus Putih (Rattus norvegicus Strain Wistar) Jantan yang merupakan penelitian true experimental post test control study, dilakukan untuk melihat perbandingan kadar TG, LDL, dan HDL antara tikus yang diberi diet normal dengan tikus yang diberi diet atherogenik. Diet tinggi lemak yang diberikan terdiri dari $50 \%$ PARS, 25\% tepung terigu, kolesterol $2 \%$, asam kolat $0,2 \%$, minyak babi $5 \%$, air $17 \%$. Menurut penelitian tersebut terdapat perbedaan kadar kolesterol LDL antara tikus yang diinduksi diet tinggi lemak selama 8 minggu dan 16 minggu karena faktor yang tidak dapat dikendalikan seperti perbedaan berat badan, faktor stress selama penelitian atau faktor lain yang belum diketahui. Peningkatan kadar kolesterol pada kelompok tikus dengan pemberian diet tinggi lemak disebabkan karena adanya penambahan kolesterol, asam kolat dan minyak babi pada pakan. Pemakaian kolesterol, minyak babi dan asam kolat bertujuan untuk menginduksi peningkatan LDL darah. Minyak babi mempunyai kandungan kolesterol yang lebih tinggi dibandingkan dengan minyak hewani lainnya dan minyak nabati. Pemberian asam kolat selama 8 minggu tidak dapat meningkatkan kadar kolesterol dan terbentuknya sel busa secara bermakna. Pada penelitian tersebut, terdapat tiga kelompok yang diberikan diet tinggi lemak dalam kurun waktu berbeda yakni 8 minggu, 16 minggu dan 22 minggu diperoleh rerata kadar LDL masing-masing yakni sebesar 141,4 mg/dl, $166 \mathrm{mg} / \mathrm{dl}$, dan $185,7 \mathrm{mg} / \mathrm{dl}$ jika dibandingkan dengan kelompok kontrol Pa diperoleh rerata LDL sebesar 63,43 mg/dl perbedaan kadar LDL cukup signifikan pada kedua kelompok perlakuan padahal diberi diet dengan tinggi lemak yang sama. Perbedaan kadar LDL dalam penelitian ini diduga karena adanya pengaruh dari lamanya pemberian induksi diet tinggi lemak Sebaliknya, komposisi diet tinggi lemak yang digunakan dalam penelitian ini terbukti efektif dalam 
meningkatkan kadar LDL pada kelompok kontrol $\mathrm{Pa}$ dan kelompok perlakuan $\mathrm{Pb}$. Pada penelitian ini diperoleh perbedaan kadar rerata LDL pada kelompok kontrol Pa dan kelompok perlakuan $\mathrm{Pb}$, yakni 63,43 $\mathrm{mg} / \mathrm{dl}$ dan $44,43 \mathrm{mg} / \mathrm{dl}$. Dengan demikian dapat disimpulkan bahwa penurunan kadar LDL pada kelompok $\mathrm{Pb}$ yakni tikus yang sebelumnya diterapi oksigen hiperbarik bertekanan 2,4 ATA dengan konsetrasi oksigen $98 \%$ dan kemudian diberikan diet tinggi lemak. Selanjutnya bila dibandingkan dengan kelompok kontrol $\mathrm{Pa}$ yang hanya diberikan diet tinggi lemak selama 7 minggu dan tanpa diterapi oksigen hiperbarik. Setianingsih dan Suryokusumo (2015) dalam penelitiannya melaporkan bahwa terapi oksigen hiperbarik (OHB) dapat menurunkan atherosklerosis seperti hiperkolesterolemia. Hal ini dapat ditunjukkan bahwa OHB dapat menurunkan kadar TG, LDL, dan meningkatkan HDL pada tekanan 1,5 ATA dan 3 ATA.

Hasil penelitian Kudchodkar et al (2000) mengenai terapi dengan oksigen hiperbarik pada kelinci yang diberi diet tinggi lemak selama satu minggu untuk menginduksi atherosclerosis. Selanjutnya setengah dari kelompok kelinci tersebut diberikan terapi oksigen hiperbarik. Diet tinggi kolesterol menginduksi hiperkolesterolemia dimana kolesterol plasma meningkat hingga lebih dari 20 kali lipat, terjadi peningkatan VLDL+IDL (>67\%), dan peningkatan LDL (>30\%), sedangkan kadar HDL menurun. Menurut Kudchodkar et al (2000) kadar LDL sampel tikus kontrol dan yang diberikan diet kolesterol memiliki perbedaan yang signifikan yakni tikus yang diberikan diet kolesterol memiliki kadar LDL yang lebih tinggi. Hal ini turut menguatkan hipotesis bahwa ada pengaruh terapi oksigen hiperbarik terhadap kadar LDL plasma. Selanjutnya, dikarenakan penelitian ini berfokus pada upaya preventif terjadinya atherosklerosis terutama dalam mencegah peningkatan LDL dengan memberikan terapi hiperbarik sebelum dilakukan induksi diet tinggi lemak. Penelitian yang dilakukan Keskin et al (2017) juga mendukung hasil penelitian ini. Keskin et al (2017), juga melaporkan bahwa terapi oksigen hiperbarik pada 29 pasien menunjukkan kadar lipid plasma dan khususnya kadar oxLDL yang menurun. Penelitian tersebut dilakukan pada pasien dengan rentang umur antara 21 dan 85 tahun yang memenuhi kriteria inklusi dengan sesi pemberian terapi oksigen hiperbarik selama 6 hari dalam seminggu. Setiap sesi terdiri atas 120 menit dan diberikan inhalasi oksigen $100 \%$ bertekanan 2,5 ATA dengan interval 5 menit setiap 30 menit, setiap sesi juga 
Pengaruh Pemberian Oksigen Hiperbarik terhadap Kadar LDL Tikus Putih (Rattus norvegicus)... Ika Apriyanti Arum Putri, Herin Setianingsih

termasuk periode kompresi dan dekompresi selama 15 menit. Hasil penelitian oleh Keskinet al (2017) dapat dilihat pada Tabel 5.

Tabel 5. Hasil penelitian oleh Keskin et al (2017)

Table 2. Mean oxidized low-density lipoprotein and other lipid levels pre and post hyperbaric oxygen treatment

\begin{tabular}{|c|c|c|c|}
\hline & Pre HBO T & Post HBOT & $p$ \\
\hline & Mean $\pm S D$ & Mean $\pm S D$ & \\
\hline Ox-LDL (U/mL) & $4.96 \pm 0.1$ & $4.94 \pm 0.1$ & 0.36 \\
\hline Total cholesterol (mg/dL) & $235 \pm 33$ & $233 \pm 32$ & 0.86 \\
\hline LDL cholesterol (mg/dL) & $147 \pm 28$ & $143 \pm 27$ & 0.73 \\
\hline HDL cholesterol (mg/dL) & $42 \pm 12$ & $41 \pm 11$ & 0.92 \\
\hline Triglyceride (mg/dL) & $200 \pm 20$ & $188 \pm 19$ & 0.11 \\
\hline
\end{tabular}

Berdasarkan Tabel 5. dapat disimpulkan bahwa rerarta kadar LDL sebelum dan sesudah terapi oksigen hiperbarik tidak memiliki perbedaan yang signifikan. Rerata kadar LDL sebelum terapi oksigen hiperbarik yakni $147 \mathrm{mg} / \mathrm{dl}$ sedangkan kadar LDL setelah dilakukan terapi oksigen hiperbarik yakni $143 \mathrm{mg} / \mathrm{dl}$. Keskin et al (2017) juga melakukan hal yang sama dengan penelitian yang kami lakukan terapi oksigen hiperbarik tanpa diinduksi diet tinggi lemak sama seperti yang dilakukan pada kelompok $\mathrm{Pb}$. Pada hasil penelitian tersebut terjadi penurunan rerata kadar LDL plasma walaupun tidak signifikan. Meskipun penelitian yang dilakukan peneliti tidak menggunakan teknik analisa sampel darah dengan pengambilan darah sebelum dan sesudah penelitian seperti pada penelitian di atas, namun kelompok
$\mathrm{Pa}$ dibandingkan dengan kelompok $\mathrm{Pb}$ mempunyai hasil yang sama dengan penelitian di atas yakni terapi hiperbarik oksigen dapat menurunkan kadar LDL plasma namun belum mencapai kadar normal. Kelemahan penelitian ini juga dapat dilihat melalui Teuku Heriansyah (2013) bahwa yang dapat mempengaruhi hasil penelitian serupa yakni pertama, minyak babi yang digunakan dalam pakan tikus menimbulkan aroma yang tengik, hal ini mempengaruhi nafsu makan tikus. Tikus dapat mengikuti bau melalui udara. Tikus juga dapat mengidentifikasi bau dari target dengan akurasi yang tinggi, tetapi pembauan akan berkurang apabila bau-bau lain ditambahkan (Gire et al, 2016). Masalah ini dapat disiasati dengan pemberian aroma atau perasa makanan pada tikus agar nafsu makan tikus tidak terlalu jelek, namun pada penelitian ini tidak digunakan penambahan aroma atau perasa pada pakan tikus sehingga nafsu makan tikus yang berbeda dapat mempengaruhi hasil pengukuran LDL pada kelompok $\mathrm{Pa}$ dan $\mathrm{Pb}$. Kedua, terdapat perbedaan berat badan sehingga dapat mempangaruhi jumlah kolesterol awal tikus, kemudian juga faktor stress selama penelitian atau faktor lain yang belum diketahui. Selain itu, menurut Lin et al (2011), adanya pendingin di dalam chamber hiperbarik atau air conditioner 
(AC) dapat menyebabkan berkurangnya konsentrasi oksigen yang juga dapat mempengaruhi hasil pada penelitian ini. Kesemua faktor ini tidak dapat diatur oleh peneliti dan secara tidak langsung dapat mempengaruhi hasil penelitian ini.

\section{KESIMPULAN}

Kesimpulan penelitian ini adalah teradapat pengaruh pemberian oksigen hiperbarik terhadap penurunan kadar LDL tikus putih (Rattus norvegicus) galur Sprague dawley yang kemudian diberi diet tinggi lemak. Hal ini dibuktikan dengan hasil uji stastistik menggunakan uji Mann Whitney dengan nilai signifikansi ( $p$ ) sebesar 0,004 atau $p<\alpha$ yang menunjukkan $\mathrm{H}_{1}$ diterima.

\section{DAFTAR PUSTAKA}

Bhutani S dan Guruswamy V, 2012. Hyperbaric Oxygen and Wound Healing. Indian Journal of Plastic Surgery. 45(2): 316-324.

Gire DH, Kapoor V, Arrighi-Allisan A, Seminara A, Murthy VN, 2016. Mice Develop Efficient Strategies For Foraging and Navigation Using Complex Natural Stimuli. Current Biology (in press).
Heriansyah T, 2013. Pengaruh Berbagai Durasi Pemberian Diet Tinggi Lemak Terhadap Profil Lipid Tikus Putih (Rattus novergicus) strain Wistar Jantan. Jurnal Kedokteran Syiah Kuala. 13(3):144-150

Sigit S, Aksono EB, Damayanti R, Bijanti R, Herwiyarirasanta I, Setyono H, 2010. Effect of Black Soybean Extract Supplementation in Low Density Lipoprotein Level of Rats (Rattus norvegicus) With High Fat Diet. Majalah IImu Faal Indonesia. 9(3):217-221.

Ishibashi M, Hayashi A, Akiyosh H, Ohashi $F$, 2014. The influences of hyperbaric oxygen therapy with a lower pressure and oxygen concentration than previous methods on physiological mechanisms in dogs. Journal of Veterinary Medical Science.77 (3):297-304.

Kemenkes RI, 2017. Penyakit Jantung Penyebab Kematian Tertinggi, Kemenkes Ingatkan Cerdik.

Kemnkes RI, 2014. Situasi Kesehatan Jantung. Pusat Data dan Informasi Kementerian Kesehatan RI, Jakarta Selatan 
Pengaruh Pemberian Oksigen Hiperbarik terhadap Kadar LDL Tikus Putih (Rattus norvegicus)... Ika Apriyanti Arum Putri, Herin Setianingsih

Keskin K, Kilci H Aksan G, Cetinkal G, Yilddiz SS, Kocaman TF, Bingo G, 2017. Serum oxidized low-density lipoprotein level as a marker of oxidative stress in patients undergoing hyperbaric oxygen therapy.Turk Kardiyol Dern Ars. 45(6): 533-537.

Kudchodkar BJ, Wilson J, Lacko A, Dory L, 2000. Hyperbaric Oxygen Reduces the Progression and Accelerates the Regression of Atherosclerosis in Rabbits. Arterioscler Thromb Vasc Biol. 20(6):1637-1643.

Kumar V, Abbas A, Aster J, 2015. Buku Ajar Patologi Robbins Edisi ke-9. Elsevier, Singapore.

Lin SY, Lin DTW, Chang CC, Huang CN, 2011. The Heat Transfer Analysis of The Hyperbaric Oxygen Chamber with Cooling System. Proceeding of the International MultiConfrence of Engineers and Computer Scientists 2011. Vol II.

Ma'rufi dan Rosita, 2014. Hubungan Dislipidemia dengan Kejadian Penyakit Jantung Koroner. Jurnal Kedokteran dan Kesehatan Indonesia. 6 (1): 47-53.
Rustika dan Ratih O, 2014. Penyakit Jantung Koroner (PJK) dengan Obesitas di Kelurahan Kebon Kalapa, Bogor (Baseline Studi Kohor Faktor Resiko PTM). Buletin Penelitian Sistem Kesehatan. 17(4): 385-393.

Sa'dah NN dan Rarastoeti P, 2016. Profil Lipid dan Indeks Aterogenik Tikus Putih (Rattus norvegicus Bekenhout, 1769) Hiperlipidemia Dengan Asupan Pelet Nasi dan Bekatul Beras Hitam (Oryza sativa L.) "Cempo Ireng". Seminar Nasional Biodiversitas VI. Surabaya.

https://www.academia.edu/3179 $5535 /$

Setianingsih H, Soetjipto, Sudiana IK, Suryokusumo MG, 2018. Hyperbaric Oxygen Effects Towards SIRT1 level in Sprague Dawley With Endothelial Dysfunction by High-cholesterol Diet. Bali Med J. 7 (2): 535-538. Setianingsih H dan Suryokusumo M, 2015. Penggunaan Oksigen Hiperbarik dalam Menurunkan Kolesterol. HKI 3.64274/2015 
ISSN 1978-2071 (Print); ISSN 2580-5967 (Online) Jurnal IImiah Kedokteran Wijaya Kusuma 8(1) : 1-13, Maret 2019

WHO, 2017. World Heart Day 2017. Xuan G dan Shunju, 2010. High density http://www.who.int/cardiovascul lipoproteins-based therapies for ar_diseases/world cardiovascular disease. Journal of heart-day-2017/en/ Cardiovascular Disease Research. 1(3):99-103. 